ЗАTВEPАЖЕНО

Наказ Міністерства охорони

зАоров'я України

$21.06 .2016 № 613$

\title{
Уніфікований клінічний протокол первинної, вторинної (спеціалізованої), третинної (високоспеціалізованої) медичної допомоги. Вірусний гепатит В У дорослих (вибрані положення)
}

ПЕРЕАІК СКОРОЧЕНЬ, ЩО ВИКОРИСТОВУЮТЬСЯ У ПРОТОКОАІ

APRI Неінвазивний тест Аіагностики стану печінки

FIB-4 Неінвазивний тест Аіагностики стану печінки

HBeAg Антиген евірусу гепатиту B

HBsAg Поверхневий антиген вірусу гепатиту B

HBV Вірус гепатиту B

HBcAg ЯАерний антиген вірусу гепатиту B

Ig Імуноглобуліни. Розрізняють імуноглобуліни різних класів: A (lgA), G (lgG), М (lgM)

METAVIR Шка^а оцінки Ааних біопсії печінки

A^T А^анінамінотрансфераза

анти- Антитіла АО віАповіАного антигену / збуАника (наприклаА, анти-HBe - антитіла Ао HBeAg)

АСТ Аспартатамінотрансфераза

ВГВ Вірусний гепатит В

ВГС Вірусний гепатит С

ВІ^ Вірус імунодефіциту АюАини

ВОО3 Всесвітня організація охорони зАоров'я

ГЦК Гепатоцелюлярна карцинома

АНК Аезоксирибонуклеїнова кислота

$3 О 3$ Зак^аА охорони ЗАоров'я

ІФН Інтерферон

КМП КАінічний маршрут пацієнта

АПМА АОкальний протокол меАичної АОПомоги

MKХ-10 Міжнародна к^асифікація хвороб 10-го перегляау

MO Міжнародна оАиниця

$\mathrm{MO} 3$

України Міністерство охорони зАоров'я України

НА Нуклеоз(т)иАні аналоги

$\mathrm{HAMH}$

України Національна акалемія меАичних наук України

Пег-ІФН Пегільований інтерферон

УКПМА Уніфікований кАінічний протокол первинної, вторинної (спеціалізованої) меАичної Аопомоги

ХГВ Хронічний гепатит В

ЦПМСА Центр первинної меАико-санітарної Аопомоги ШКФ ШвиАкість клубочкової фільтрації

\section{Oпис етапів медичної допомоги}

\section{1. Профілактика вірусного гепатиту В}

Первинна профілактика спрямована на попередження інфікування особи, а в разі інфікування на своєчасну Аіагностику іпочаток ^ікування, що є запорукою оАужання. Первинна профілактика інфікування полягає в обізнаності населення щоАо проблеми ВГВ та Аотримання певної повеАінки. Така поведінка передбачає утримання віА Контактів з ріАинами організму іншої люАини (кров, міжтканинна ріАина, сперма): треба практикувати безпечний (захищений) секс (застосовувати бар'єрні контрацептиви -презервативи), користуватися засобами разового (шприци, голки, крапельні системи, гінекологічні огляАові Азеркала тощо) та інАивіАуального (зубні щітки, леза Аля гоління, контактні лінзи) призначення; користуватися засобами інАивіАуального захисту (рукавички, окуляри, фартухи тощо), користуватися стерильним інструментом багаторазового призначення (манікюрний, стоматологічний, хірургічний, ^абораторний інструмент, інструмент А^я пірсингу і татуажу тощо); працівникам, які мають контакт з ріАинами та тканинами організму, не Аопускати забруАнення навколишнього сереАОвища останніми та користуватися засобами інАивіАУального захисту.

Особам, які мали (або не виключають) контакт з ріАинами організму іншої ^юАини, звертатися Ао сімейного лікаря з привоАУ своєчасної Аіагностики хвороби, оскільки чим раніше буАе встановлений Аіагноз, тим скоріше можна буАе прийняти рішення стосовно лікування.

Аля запобігання передачі ВГВ віА матері Ао Аитини найбільш важАивою стратегією $€$ наАання першої Аози вакцини проти гепатиту В якомога швиАше після нароАЖення, переважно впроАОВж 24-х ГОАИн з пОАальшими, щОНайменше АвОМа, СвоєчаСними наступними АОзами. HBsAg позитивним вагітним із вірусним навантаженням $2 \times 10^{5}$ МО/м^ та більше показане призначення тенофовіру Аизопроксилу, телбівуАину або ^амівудину у третьому триместрі вагітності.

Вторинна профілактика спрямована на попереАження поширення вірусу в навколишнє сереАовище інфікованою особою та зменшення тяжкості перебігу хвороби шляхом моАифікації способу життя.

Суть вторинної профілактики: інфікована особа має усвіАом^ювати суть своєї хвороби (етіологія, ш^ях переАачі вірусу, насліА- 
ки хвороби Аля організму) і, як сумлінний член суспільства, повоАитися безпечно по віАношенню АО інших АюАей, пам' ятаючи про те, що саме вона може інфікувати іншого.

Інфіковані особи не повинні брати участі у програмах АОнорства (крові, органів, сперми тощо). Всі особи, які мають контакт з біологічними ріАинами, повинні бути обстежені та щеплені проти ВГВ.

Щеплення Аорослих осіб, що належать Ао груп епіАеміологічного та клінічного ризиків, регламентоване чинним Календарем профілактичних щеплень в Україні.

Інфіковані НВV пороАімлі мають забезпечити можливість обстеження своєї новонародженої Аитини в строк, зазначений лікарем, а також своєчасне щеплення проти ВГВ.

Немає ризику передачі HBV віА інфікованої матері Ао її новонароАженої Аитини при груАНому вигоАОвуванні, якщо Аитині провоАиться щеплення проти ВГВ.

Зміна способу життя (зменшення або віАмова віА вживання алкоголю, нормалізація маси тіла, віАмова віА куріння) сприяє покращенню стану зАоров'я пацієнта.

\section{2. Групи ризику ВГВ}

У групу ризику вхоАять особи, які піААаються впливу факторів, що піАвищують ризик інфікування HBV. Враховуючи це виАіляють наступні групи ризику:

0. Реципієнти крові / тканин.

1. Пацієнти на гемодіалізі.

2. МеАичні працівники, Аіяльність яких передбачає провеАення процеАур, що становлять ризик інфікування (хірурги, травмато^оги, акушери-гінекологи, ^аборанти, маніпуляційні меАсестри та ін.), а також працівники служб наАзвичайних ситуацій в разі поранення гострими інструментами або попаАання на слизові оболонки крові, що інфікована ВГВ.

3. Пацієнти з піАвищеним рівнем активності А^Т нез'ясованої етіології.

4. Особи, які споживали / споживають ін'єкційні наркотики.

5. Особи, які $\in \mathrm{BI} \wedge$-позитивними.

6. Особи, які перебували в заклалах позбавлення волі впроАОвж останніх 6 міс; в' язні.

7. Особи, які отримали медичну чи стоматологічну Аопомогу в країнах, Ае ВГВєпоширеним, а інфекційний контроль $є$ низьким.

8. Особи, у яких $\in$ татуювання або пірсинг.

9. Особи, які мали статевого партнера / побутові контакти 3 особою, яка інфікована ВГВ.

10. Чоловіки, які мають сексуальні стосунки з чоловіками.

11. Працівники комерційного сексу.

12. Транссексуали.

Ці пацієнти інформуються ^ікарем про їхню належність Ао групи високого ризику інфікування HBV. Їм має бути запропоноване проведення віАповіАного обстеження і, при необхіАності, щеплення.

\section{3. Етіологія і патогенез вірусного гепатиту В}

ВиАі^яють наступні антигени вірусу: HBsAg, HBcAg і HBeAg. При цьому виАі^яють 9 генотипів вірусу (віА А АО I).

Механізми передачі вірусу включають: черезшкірний і слизово-контактний (Контакт з інфікованою кров'ю, слиною, менстру- альними і вагінальними виАіленнями, спермою та іншими ріАинами організму). Ризик розвитку ХГВ при інфікуванні в Аорослому віці менше ніж $5 \%$.

Після інфікування в організмі розвивається патологічний стан, в якому виАіляють наступні фази: імунотолерантна, імуноактивна, імунного контролю, уникнення імунної віАповіАі, реактивації (Аив. табл. 1).

\section{4. Аіагностика та визначення стаАії ВГВ}

ПривоАОм А^я провеАення Аіагностичного пошуку можуть бути: фактори ризику розвитку ВГВ, клінічна картина, що вписується в кАінічну картину ВГВ, позитивний HBsAg. У разі виявлення HBsAg всім пацієнтам провоАиться Комп^екс первинної Аіагностики (Аив. АОАаток 2).

Метою Аіагностики є: а) піАтверАження факту інфікування HВV; б) визначання ступеня ураження печінки; прийняття зваженого рішення щодо стратегії та тактики веАення пацієнта.

Пацієнт інформується лікарем, який провоАить оцінку Ааних тестів, що Аіагностичні метоАи Аають хибнопозитивні і хибнонегативні результати. При цьому пацієнту роз' яснюється, що це означає Аля нього. Супутня патологія (стани) можуть впливати на показники Аіагностичних тестів: зловживання алкоголем може призвоАити АО піАвищення АСТ; малярія або ВІ^ можуть бути причиною тромбоцитопенії; вживання наркотиків або лікарських фітопрепаратів можуть бути причиною піАвищених значень APRI; гострий гепатит або загострення хронічного, застійна серцева неАостатність або неАавно спожита їжа та інші чинники можуть стати причиною завищених показників щільності печінки.

Враховуючи низьке прогностичне позитивне значення тесту APRI, як і інших неінвазивних методів Аіагностики фіброзу/цирозу печінки (наприк^аА, FIB-4, FibroTest, FibroScan), багато випалків цирозу можуть бути пропущені при використанні лише неінвазивних метоАів Аіагностики. Тому важАиво, щоб неінвазивні метоАИ Аіагностики використовувалися разом з клінічними критеріями та іншими методами Аіагностики (наприк^аА, А^Т, рівень вірусного навантаження) Аля виявлення тих, хто потребує лікування.

Аіагностика ВГВ починається з лабораторної Аіагностики (Аив. пункт 4.4.4).

У 3О3, що наАають вторинну МеАИчну АопомоГу, пацієнти направляються лікарями первинної меАичної Аопомоги з результатами провеАеної первинної Аіагностики (Аив. Аодаток 2). Аікарі спеціалісти (інфекціоністи, гастроентерологи) провоАять поАальше обстеження пацієнта з урахуванням Ааних вже провеАених виАів обстеження.

\section{1). Скарги}

При гострому гепатиті скарги можуть 3' являтися через Аекілька місяців після інфікування НBV. Пацієнт може скаржитися на втомленість, головний біль, знижений апетит, нуАоту, блювання, абломінальний біль, біль в правому піАребер'ї, субфебрильну температуру, жовтуху, темний колір сечі, випорожнення світлого кольору, артралгію, висипку. У інших пацієнтів симптоми можуть бути віАсутніми.

Більшість пацієнтів з ХГВ асимптоматичні. Може віАмічатися неспецифічна симптоматика: втомленість, легкий біль в правому піАребер'ї. У пацієнтів з тяжким перебігом або у пацієнтів з цирозом 
Таблиця 1. Фази хронічного гепатиту В

\begin{tabular}{|c|c|c|c|}
\hline Фаза & $\begin{array}{l}\text { Серологічний } \\
\text { статус НBeAg }\end{array}$ & Характеристика & $\begin{array}{c}\text { Показання } \\
\text { до лікування }\end{array}$ \\
\hline 1. Імунотолерантна & $\begin{array}{l}\text { HBeAg- } \\
\text { позитивний }\end{array}$ & $\begin{array}{l}\text { Етап, який спостерігається у багатьох НBeAg-позитивних дітей і молодих дорослих, особли- } \\
\text { во серед тих, хто інфікований в перинатальному віці або в період раннього дитинства. } \\
\text { Мінімальна тяжкість хвороби, підтверджена гістологічно. } \\
\text { Вона, як правило, зберігаєтья в молодому віці і може тривати 10-30 років після перинатального } \\
\text { інфікування. } \\
\text { Як правило, виявляється сироватковий } \mathrm{HBeAg,} \mathrm{рівні} \mathrm{ДНК} \mathrm{НBV} \mathrm{високі} \mathrm{(зазвичай} \mathrm{>} 200000 \\
\text { МО/мл) і АЛТ може бути стійко нормальною або мінімально підвищеною. Існує мінімальне } \\
\text { запалення печінки, немає або повільне прогресування фіброзу і низька спонтанна втрата } \\
\text { НВеАg }\end{array}$ & $\begin{array}{l}\text { Лікування, } \\
\text { як правило, } \\
\text { не показано, } \\
\text { але моніторинг } \\
\text { потрібен }\end{array}$ \\
\hline $\begin{array}{l}\text { 2. Імуноактивна } \\
\text { (НВеАg-позитивний } \\
\text { хронічний гепатит) }\end{array}$ & $\begin{array}{l}\text { HВеAg- } \\
\text { позитивний; } \\
\text { може } \\
\text { розвиватися } \\
\text { анти-НВе }\end{array}$ & $\begin{array}{l}\text { Підвищені або періодично підвищені рівні АЛТ. } \\
\text { Високий рівень реплікації вірусу або рівень, що коливається (ДНК НВV >2 } 000 \text { МО/мл). } \\
\text { Гістологічно визначається некрозапальна активність. } \\
\text { Сероконверсія щодо НВеAg (поява анти-НВе) можлива з нормалізацією АЛТ, яка призво- } \\
\text { дить до фази «імунного контролю». } \\
\text { Можуть бути симптоми гепатиту, але є більш тяжкий гістологічно підтверджений гепатит і } \\
\text { фіброз. Ця фаза може тривати від декількох тижнів до декількох років. Показники серокон- } \\
\text { версії вище у тих, у кого підвищений рівень сироваткової амінотрансферази і у інфікованих } \\
\text { генотипами D, А, F і В }\end{array}$ & $\begin{array}{l}\text { Лікування може } \\
\text { бути показане }\end{array}$ \\
\hline $\begin{array}{l}\text { 3. Неактивний ХГВ } \\
\text { або фаза «імунного } \\
\text { контролю» }\end{array}$ & $\begin{array}{l}\text { HBeAg- } \\
\text { негативний, } \\
\text { анти-НВе } \\
\text { позитивний }\end{array}$ & $\begin{array}{l}\text { Стійкий нормальний рівень АЛТ. } \\
\text { Низький або такий, що не визначається тест-системами, рівень ДНК НВV (ДНК НВV } \\
<2000 \text { МО/мл). } \\
\text { Ризик цирозу і ГЦК знижений. } \\
\text { Слідує за успішною сероконверсією (від НВеAg-позитивного стану до появи анти-НВе). } \\
\text { Після того, як НВеAg зникає, прояви хвороби можуть зменшитися з мінімальним прогре- } \\
\text { суванням фіброзу і поверненням сироваткових рівнів АЛТ до нормальних з низькми або } \\
\text { такими, що не визначаються тест-системами рівнями ДНК НВV (<2 } 000 \text { МО/мл). Серокон- } \\
\text { версія НВеАg в молодому віці до настання серйозної хвороби печінки дає хороший прогноз } \\
\text { - зменшення ризику цирозу і раку печінки. Проте у деяких осіб може з'явитися активна } \\
\text { вірусна реплікація }\end{array}$ & $\begin{array}{l}\text { Лікування взагалі } \\
\text { не показане, але } \\
\text { необхідний } \\
\text { моніторинг щодо } \\
\text { реактивації і ГЦК }\end{array}$ \\
\hline $\begin{array}{l}\text { 4. «Уникнення імунної } \\
\text { відповіді» (НВеАg- } \\
\text { негативний ХГВ) }\end{array}$ & $\begin{array}{l}\text { НВеAg-негативний } \\
\text { з або без } \\
\text { HBsAg-позитивності }\end{array}$ & $\begin{array}{l}\text { Аномальний рівень АЛТ (постійно або періодично). } \\
\text { Реплікація вірусу гепатиту В від помірної до високої (ДНК НВV >20 } 000 \text { МО/мл). } \\
\text { Старші люди, особливо з ризиком прогресування хвороби (фіброз/цироз). } \\
\text { Зустрічається приблизно у 5-15\% НВеAg-негативних, анти-НВе-позитивних осіб в неак- } \\
\text { тивному стані носія. НВеAg не визначається (і виявляється анти-НВе). Це представляє собою } \\
\text { більш пізню фазу хвороби, як правило, у літніх людей, і має різний перебіг з аномальними } \\
\text { або перемінними рівнями АЛТ і ДНК НВV, некрозапальними змінами і більш швидким про- } \\
\text { гресуванням цирозу (річний показник 8-20\%) }\end{array}$ & $\begin{array}{l}\text { Лікування може } \\
\text { бути показане }\end{array}$ \\
\hline $\begin{array}{l}\text { 5. «Реактивація" } \\
\text { або «загострення } \\
\text { хронічного } \\
\text { гепатиту» }\end{array}$ & $\begin{array}{l}\text { HBeAg- } \\
\text { позитивний або } \\
\text { негативний }\end{array}$ & 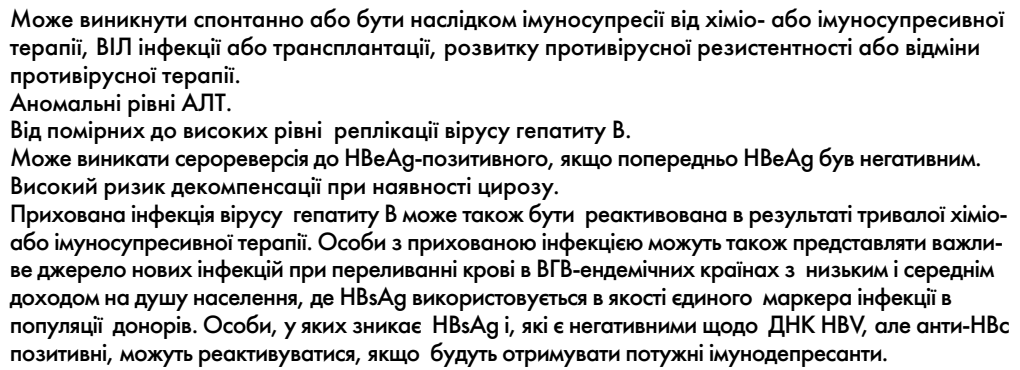 & $\begin{array}{l}\text { Лікування } \\
\text { показане }\end{array}$ \\
\hline
\end{tabular}

можуть віАмічатися жовтуха, зірчасті гемангіоми, Аолонна еритема, спленомегалія, гінекомастія, печінковий запах з рота. У пацієнтів 3 цирозом можуть зустрічатися асцит, периферійні набряки, енцефалопатія, шлунково-кишкові кровотечі. Окрім цього можуть зустрічатися позапечінкові прояви: вузликовий періартеріїт, нефропатія (в тому числі мембранозний гломерулонефрит, мембранознопро^іферативний гломерулонефрит, кріоглобулінемія (тип II).

\section{2). Анамнез}

При зборі анамнезу з'ясовується, чи належить пацієнт Ао групи ризику за ВГВ, а також чи має обтяжений сімейний анамнез щоАо тяжких уражень печінки різної етіології.

\section{3). Фізикальне обстеження}

При фізикальному обстеженні увага акцентується насампереА на кАінічних симптомах цирозу печінки з метою його виключення: іктеричності склер та наявності жовтухи, зірчастих ангіомах, наяв- ності Аолонної еритеми, гінекомастії, гепатомегалії та спленомегалії, болісності в проекції печінки, асциті, периферичних набряках та інших.

\section{4). Аабораторна Аіагностика}

^абораторна Аіагностика ВГВ починається з визначення HBsAg. Всі пацієнти з позитивним результатом тесту на HBsAg обстежуються на наявність НВеAg, антитіл ( $\mathrm{lgM}$, IgG або сумарні: анти-НBs, анти-НВе, анти-НВс); кількісно визначається АНК HBV (в МО/^), оцінюється стан печінки (АИв. пункт 4.4.5). Пацієнти з позитивним HBsAg обстежуються на вірусний гепатит D (анти-HDV загальні), ВГС (анти-ВГС IgG), вірусний гепатит А (анти-ВГА IgG), ВІ^ (анти-ВІ^ загальні). А^я ^абораторної Аіагностики ВГВ використовують Аані загального аналізу крові (включаючи тромбоцити), біохімічні показники крові (A^Т, АCТ, ^ужна фосфатаза, загальний білірубін, гамма-глутамілтрансфераза, альбуміни; розраху- 
нок протромбінового часу та міжнародного нормалізованого співвіАношення).

Верхньою межею норми Аля А^Т сліА вважати верхню межу норми тієї ^абораторії, в якій виконувалось тестування. Стійким нормальним (або піАвищеним) рівнем А^Т сліА вважати результат на основі Ааних трьох визначень рівнів А^Т нижче / вище верхньої межі норми, отримані в Аовільні інтервали впродовж 6-12 місяців або через попередньо визначені інтервали впродовж 12-місячного періоду. В тих випаАКах, коли неможАиво провести тестування на рівень $\triangle H К$ HBV (кількісний метоА), а рівні А^Т піАвищені, викАючаються наступні стани: порушення толерантності Ао гАюкози, АисліпіАемія, жировий гепатоз.

В залежності віА Ааних лабораторної Аіагностики виАіляють наступні стани:

1. Гострий ВГВ: позитивний HBsAg, загальні антитіла АО HBsAg негативні; антитіла (IgM) Ао HBcAg позитивні, якісний аналіз на $\triangle \mathrm{HK}$ HBV позитивний, А^Т може бути в нормі або піАвищена.

2. ОАужання ВіА ВГВ: негативний HBsAg, загальні антитіла АО HBsAg позитивні, загальні антитіла Ао HBcAg позитивні, антитіла ( $\operatorname{lgM})$ АО HBcAg не вияв^яються, якісний аналіз на АHК HBV негативний; ААТ в нормі.

3. ХГВ, НВеAg-позитивний: персистенція HBsAg впродовж $>6$ міс., загальні антитіла АО НBsAg не вияв^яються, загальні антиті^а АО HBCAg позитивні, антиті^а к^асу IgM АО HBcAg у більшості хворих не вияв^яються (ОАночасна наявність антиті^ К^асів IgG та IgМ можлива ^ише при високій активності інфекційного процесу), HBeAg позитивний, загальні антитіла Ао HBeAg не виявляються; АНК HBV >20 000 МО/м^, А^Т постійно чи періоАично піАвищена, Аані обстеження, які свіАчать про наявність некрозапальної активності та / або вираженого фіброзу.

4. ХГВ, НВеAg-негативний: позитивний HBsAg впроАовж >6міс., HBeAg не вияв^яєтьСя, загальні антитіла Ао НBeAg позитивні, АНК HBV 2000 - 20000 МО/м^, А^Т постійно чи періодично піАвищена, Аані обстеження, які свіАчать про наявність некрозапальної активності та / або вираженого фіброзу.

5. Неактивний носій: позитивний HBsAg впроАовж >6 міс., загальні антитіла Ао HBsAg не вияв^яються, загальні антитіла АО HBCAg позитивні, HBeAg не вияв^яється, загальні антитіла АО HBeAg позитивні, АHK HBV <2 000 МО/м^, А^Т постійно нормальна або не перевищує Авох верхніх норм, Аані про некрозапальну активність та / або виражений фіброз віАсутні.

В осіб з ХГВ позитивний результат HBeAg зазвичай вказує на наявність активної реп^ікації ВГВ і високої інфекційності.

У пацієнтів при віАсутності HBsAg та наявності анти-НBC IgG (або сумарних антитіл) рекоменАОвано провоАити АОАаткове обстеження.

\section{5). Оцінка стану печінки}

Оцінка стану печінки провоАиться оАним чи Аекількома неінвазивними метоАами: розрахунком інАексу АРRI (АИв. АоАаток 3), ^абораторними (у вигляАі комплексів типу FibroTest, ультразвукової Аіагностики, А^Т, АCТ, гамма-глутамілтрансфераза, альбуміни, глобуліни, загальний білірубін, протромбіновий час, а-фетопротеїн), оАним з різновиАів еластографічного обстеження печінки (транзиторна еластометрія, RT-еластографія). Вибір методу оцінки стану печінки ґрунтується на конкретній кАінічній ситуації, супутній патології, результатах попереднього обстеження, ресурсних можливостях $3 О 3$ та з урахуванням впоАобань пацієнта.

В сумнівних випаАКах (коли неможливо визначити кАінічну тактику веАення пацієнта) консиліум приймає рішення про Аоцільність проведення біопсії. При цьому враховується позиція пацієнта; лікарі інформують пацієнта про Аіагностичні можливості біопсії та імовірні ризики Аіагностичного метоАу. А^я оцінки біопсії використовується шкала METAVIR.

Tаблиця 2 Шкала оцінки біопсії печінки METAVIR

\begin{tabular}{|c|c|c|c|c|c|}
\hline $\begin{array}{c}\text { Стадія } \\
\text { Метавір }\end{array}$ & F0 & F1 & F2 & F3 & F4 \\
\hline $\begin{array}{c}\text { Визна- } \\
\text { чення }\end{array}$ & $\begin{array}{c}\text { Немає } \\
\text { фіброзу }\end{array}$ & $\begin{array}{c}\text { Портальний } \\
\text { фіброз без } \\
\text { перегородок }\end{array}$ & $\begin{array}{c}\text { Портальний } \\
\text { фіброз } \\
\text { зерегород- } \\
\text { ками }\end{array}$ & $\begin{array}{c}\text { Численні } \\
\text { перегородки } \\
\text { без цирозу }\end{array}$ & Цироз \\
\hline
\end{tabular}

\section{6). Аиференційний Аіагноз ВГВ}

Аиференційну Аіагностику ВГВ провоАять з вірусними гепатитами A, C, E; аутоімунним гепатитом, алкогольним гепатитом, ВI^інфекцією, гемохроматозом, хворобою Вільсона, Аефіцитом альфа-1 антитрипсину; меАикаментозним гепатитом та ін. Впродовж 18 Анів після щеплення проти гепатиту В у крові пацієнта може визначатися HBsAg.

\section{5. Скринінг на ВГВ}

Скринінгу на ВГВ - визначення HBsAg - піАлягають пацієнти 3 груп ризику (Аив. пункт 4.2); Аонори крові, органів та тканин; вагітні жінки; особи, які потребують імуносупресивного лікування; пацієнти з піАвищеною активністю А^Т та АСТ невіАомого похоАження, а також з ультразвуковими ознаками уражень печінки.

У разі виявлення НBsAg всім пацієнтам провоАиться комплекс первинної Аіагностики (Аив. АоАаток 2).

\section{6. Аікування}

\subsection{1. Аікування показане:}

всім хворим на ХГВ та цироз печінки (за клініко-^абораторними та / або інструментальними ознаками), незалежно віА рівнів A^T, наявності / віАсутності HBeAg чи рівнів $\triangle H K$ HBV; Аорослим (старше 18 років) з ХГВ незалежно віА HBeAg статусу, Аля яких наявні всі наступні умови: а) віАсутні кАінічні ознаки цирозу; б) мають вік Ао 30-ти років (вкАючно); в) мають стійко піАвищену активність А^Т; г) рівень АНК HBV >20 000 МО/м^; особам з позапечінковими проявами ВГВ, в тому числі гломерулонефритом або васкулітом.

\section{Аікування розгляАається А^я:}

1) осіб з АHК HBV >2000 МО/м^ та стійко піАвищеною активністю А^Т та помірно чи наАмірно вираженим запально-некротичним процесом та/чи фіброзом F2 - F3 (METAVIR) за результатами біопсії чи неінвазивних методів Аіагностики. При цьому, якщо АНК HBV $>2000$ МО/^ і має місце помірно чи наАмірно виражений запально-некротичний процес, навіть при нормальних рівнях $\mathrm{A} \wedge \mathrm{T}$, Аікування показане;

2) HBeAg-позитивних пацієнтів у фазі імунної толерантності старше 30-ти років з ГЦК в сімейному анамнезі; 
3) пацієнтів з активним за результатами біопсії ХГВ (незалежно віА HBeAg статусу) зі стійко нормальною активністю А^Т та АНК $\mathrm{HBV}>20000 \mathrm{MO} / \mathrm{M} \wedge$.

\subsection{2 Аікування не рекоменаується А^я наступних груп}

1) особам без клініко-лабораторних та інструментальних ознак цирозу, незалежно віА статусу HBeAg чи віку, А^я яাких виконуються всі з наступних умов: а) стійкі нормальні рівні А^Т; б) рівень $\triangle H K H B V<2000 \mathrm{MO} / \mathrm{M} \wedge$.

2) НВеAg-позитивним особам віком $\leq 30$ років зі стійким нормальним рівнем А^Т.

4.6.3. Моніторинг А^я тих, кому Аікування не рекоменАоване

Постійний моніторинг рекоменАОваний тим, кому Аікування не рекоменаується (АИв. пункт 4.6.2). Моніторинг проводиться 3 метою раннього виявлення тих, кому буде показане лікування. Ао них віАносяться: особи без клініко-^абораторних та інструментальних ознак цирозу віком $\leq 30$ років з рівнем АHК HBV >20 000 МО/ м^, але стійко нормальним рівнем А^Т; HBeAg-негативні особи без клініко-лабораторних та інструментальних ознак цирозу віком $\leq 30$ років з рівнем АHК HBV 2000 - 20000 МО/м^, або які мають періодично піАвищені рівні А^Т; особи без клініко-^абораторних та інструментальних ознак цирозу віком $\leq 30$ років з постійно нормальними рівнями А^Т, незалежно віА статусу НBeAg, за умови, що тестування на АНК HBV неАоступне.

\subsection{4. Аікування гострого ВГВ}

Немає потреби в проведенні противірусного ^ікування при неуск^алненому кАінічному перебігу гострого ВГВ, оскільки у $>95 \%$ імунокомпетентних Аорослих вірус спонтанно зникає. Проте, якщо є загроза хронізації (затяжна, понаА 60 Анів, персистенція НBeAg) противірусна терапія проводиться лише НА. ОАужання супровоАжується кліренсом HBsAg та сероконверсією (поява анти-НBs), як прави^о, впродовж 3-х місяців. Аікування НА також розгляАається А^я пацієнтів з фульмінантним або тяжким перебігом гострого ВГВ. При фульмінантному ВГВ може розгляАатися Аікування тенофовіру Аизопроксилом. Тривалість лікування визначається лікуючим лікарем в залежності віА кАінічної ситуації і ск^аАає щонайменше 3 місяці після АОсягнення сероконверсії (зникнення HBsAg і поява анти-HBs); або щонайменше 12 місяців після Аосягнення сероконверсії (зникнення HBeAg і поява анти-НBe) при збереженні HBsAg.

\subsection{5. Аікування хронічного ВГВ}

Метою противірусного лікування є зменшення некрозапальних змін у печінці та ступеня ії фіброзу, які призвоАять Ао прогресування хвороби, цирозу печінки, Аекомпенсованого цирозу і печінкової неАостатності, ГЦК та смерті.

А^я Аікування ВГВ використовуються НА та пегільовані інтерферони (Пег-ІФН).

Аналоги нук^еозиАів (НА) - препарати першої ^інії - $є$ си^ьними інгібіторами реплікації АHК HBV; Аікування цими препаратами $€$ Аовготривалим і може тривати пожиттєво. Ао переваг НА віАносяться: зручність ввеАення (ОАин раз на Аень перорально), низький рівень побічних реакцій, Аобра переносимість і мінімальна потреба у моніторингу токсичності; Аеякі з цих препаратів можуть застосовуватися особами із супутньою патологією (наприк^аА, ВІ^, туберкульоз) або вагітними.

Позитивні сторони застосування Пег-ІФН: обмежена тривалість лікування (курс), віАсутність резистентності і, можливо, більш висо- ка швиАкість втрати HBsAg. НеАОАіки використання Пег-ІФН: помірний противірусний ефект, потребує парентерального ввеАення, незручні у використанні, гірше переносяться і вимагають ретельного моніторингу; не можуть застосовуватися у вагітних жінок та пацієнтів з Аекомпенсованою функцією печінки.

Спочатку сліА розглянути можливість лікування Пег-ІФН. Найбільшої ефективності віА лікування Пег-ІФН сліА очікувати у хворих з високою активністю А^Т (більше 2-5×ВМН) та / або високою гістологічною активністю, віАсутністю значного фіброзу або цирозу печінки, низьким вірусним навантаженням, низьким рівнем HBsAg (Ао 20000 МО/м^) та переважно генотипами А та В ВГВ.

Також лікування Пег-ІФН сліА розгляАати (якщо інтерферони не протипоказані) в таких випалках:

а) ^ікування НА протипоказане або неефективне;

б) Аоступні метоли визначення вірусного навантаження АНК HBV і його генотипування;

в) Аоступний інтерферон;

г) супутне інфікування вірусом гепатиту D.

Перед початком лікування оцінюється тяжкість хвороби печінки; рівень вірусної реплікації; наявність супутніх хвороб; пацієнт інформується щоАо зменшення переАачі ВГВ іншим, щоАо впливу способу життя на перебіг хвороби і успіх Аікування; оцінюються фактори ризику Аисфункції нирок і початкова функція нирок; паціЄНт КОнсультується Аікуючим ^ікарем щоАО показань АО лікування, в тому числі щоАО можАивої користі і побічних ефектів, готовності АО Аовготривалого лікування і необхіАності візитів Ао ^ікаря А^я поАальшого моніторингу піА час і поза лікуванням; про важливість повного АОтримання Аікування, щоб воно було ефективними і був менший ризик медикаментозної резистентності і фінансових насліАків.

У кожного пацієнта Ао початку противірусного лікування розГАЯАаєтьСя вИзначення вихіАНОї функції нирок і оцінка вихіАного ризику Аисфункції нирок.

Вимірювання вихіАної функції нирок включає: рівень креатиніну в сироватці крові і визначення розрахункової швиАКості кАубочкової фільтрації (ШКФ) віАпОвіАНО АО АОАатка 4.

Фактори високого ризику Аисфункції нирок вкАючають: Аекомпенсований цироз печінки, кАіренс креатиніну $<50$ м^/Хв, похилий вік, індекс маси тіла (IMT) <18,5 кг/м² (або маса тіла <50 кг), погано контрольована гіпертензія, протеїнурія, неконтрольований Аіабет, активний гломерулонефрит, трансп^антація соліАних органів, супутнє застосування нефротоксичних ліків або збільшення АОзи інгібітора протеази А^я Аікування ВІ^.

При призначенні НА Аорослим пацієнтам (старше 18-ти років) препаратом першої лінії $€$ НА з високим бар'єром резистентності (тенофовіру Аизопроксил). НА з низьким бар'єром резистентності (^амівуАин, телбівуАин) можуть призвести Ао ^ікарської резистентності і не рекоменАУються АО застосування.

У осіб з піАтверАженою або піАозрюваною противірусною резистентністю (тобто історія попереАньої експозиції або первинної віАсутності віАповіАі) Ао ^амівуАину або телбівуАину призначається Аікування тенофовіру Аизопроксилом.

\section{Аікування Пег-ІФН}

Мета лікування Пег-ІФН полягає в Аосягенні стійкої вірусологічної віАповіАі (АОсягення рівня АНК HBV<2000 МО/м^ впроАОвж 
12-ти місяців після Аікування). Бажаним результатом лікування $€$ стійка HBeAg-сероконверсія в поєАнанні з нормалізацією активності А^Т і рівень АНК HBV<2000 МО/м^. Оптимальним результатом лікування вважається стан, при якому АНК НBV в сироватці крові не визначається впроАовж поАальшого періоАу спостереження (методом полімеразної ланцюгової реакції в режимі реального 4acy).

Аікування Пег-ІФН не призначається пацієнтам з позапечінковими проявами ВГВ, аутоімунними захворюваннями, пацієнтам 3 трансплантованою ниркою, вагітним жінкам та пацієнтам з Аекомпенсацією печінкової функції.

Пацієнткам, Аля яких розгляАається лікування Пег-ІФН, провоАиться тест на вагітність ( $\beta$-хоріонічний гонаАОтропін АЮАини); при негативному результаті тесту можливе лікування Пег-ІФН. При цьому пацієнтці наголошують на необхіАності Аотримуватися контрацепції піА час всього курсу лікування. У разі настання вагітності впродовж курсу Аікування Пег-ІФН схема Аікування переГАЯА

Курс лікування Пег-ІФН склаАає 48 тижнів незалежно віА HBeAg-статусу пацієнта.

Впродовж першого місяця Аікування пацієнт щотижня оцінюється на предмет наявності побічних реакцій; щотижня перевіряється техніка виконання ін' Єкцій Пег-ІФН.

Після закінчення курсу лікування пацієнт огляАається лікуючим лікарем (інфекціоністом, гастроентерологом) кожні 6 місяців. У разі, коли HBsAg не визначається, пацієнт огляАається лікуючим лікарем (інфекціоністом, гастроентерологом) кожні 12 місяців. Якщо у пацієнта при Авох поСАіАОВних ОГАЯАах визначаєтьСЯ анТИHBs, такий пацієнт не потребує поАальшого нагляАу і знімається 3 ПОАЯАЬШОГО НаГАЯАУ.

При ^ікуванні пацієнта Пег-ІФН провоАяться наступні обстеження:

\section{HBeAg-позитивні:}

ЗАК, білірубін, альбумін, А^Т, сечовина, креатинін, ТТГ - АО початку лікування, на 2, 4, 12, 24, 36 та 48 тижнях з метою виявлення побічних реакцій. HBsAg та анти-НВs визначається на 24-му та 48-му тижнях віА початку лікування та на 24-му та 48-му тижнях піс^я закінчення Аікування. Також HBsAg визначається на початку лікування.

На 12-му тижні лікування проводиться обстеження на HBsAg (за можливості кількісне визначення) та $\triangle \mathrm{HK}$ HBV. У разі, якщо $\triangle H K \mathrm{HBV} \geq 20000 \mathrm{MO} / \mathrm{M} \wedge$ та / або не зменшився HBsAg, порівняно 3 вихіАним рівнем, вирішується питання про припинення Аікування Пег-ІФН.

Також HBsAg та АHК HBV визначається на 24-му тижні віА початку лікування. Якщо на 24-му тижні HBsAg >20 000 МО/м^ та / чи не Аосягнуто зниження АHK HBV більше ніж на $2 \log 10$ МО/м^, то вирішується питання про припинення Аікування Пег-ІФН.

\section{HBeAg-негативні:}

ПереА початком Аікування проводяться обстеження: ЗАК, білірубін, альбумін, А^Т, сечовина, креатинін, згортальна функція крові, АНК HBV (кількісно), співвіАношення білок / креатинін.

ЗАК, АЛТ - щомісячно впроАОвж року; ТГГ - Кожні 3 місяці впроАОвж року. АНК HBV (кількісно) визначається на 12-му, 24-му та 48-му тижнях віА початку лікування та на 24-му та 48-му тижнях після

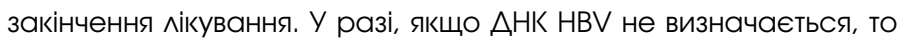
визначається HBsAg (кожні 12 місяців). В тому випалку, коли не визначається HBsAg, пацієнт обстежується на анти-HBs. Якщо на 12-му тижні не Аосягнуто зниження HBsAg та / чи не Аосягнуто зниження АHК HBV більше ніж на $2 \log 10$ MO/м^, то вирішується питання про припинення лікування Пег-ІФН.

Також HBsAg та AHK HBV визначається на 24-му тижні віА початку лікування.

\section{Неефективність мікування}

Первинна неефективність противірусної терапії НА визначається яК віАСутність зниження рівня АНК HBV нa $\geq 1 \log 10 \mathrm{MO} / \mathrm{M} \wedge$ впродовж 3-х місяців після початку лікування. Вторинна неефективність противірусного Аікування визначається при збільшенні рівнів $\triangle H \mathrm{KK} \mathrm{HBV} \mathrm{в} \geq 1 \log 10$ МО/м^ віА попереАнього визначення у осіб з початковим противірусним ефектом Аікування (зниження в сироватці АНК HBV $\geq 1 \log 10 \mathrm{MO} / \mathrm{M} \wedge$ ).

ПіАвищення рівня А^Т при неефективності лікування НА, як правило, віАбувається пізно і $є$ віАНосно поганим прогностичним маркером розвитку резистентності.

\section{Припинення Аікування}

Всі особи з цирозом потребують Аовічного лікування НА і не повинні припиняти противірусну терапію через ризик реактивації, яка може призвести Ао серйозних уражень печінки.

Припинення Аікування НА може розгАяАатися вИкАючно у: осіб без кАінічних проявів цирозу, які можуть бути Аовгий час піА ретельним спостереженням з привоАу реактивації, і, якщо $є$ Аокази втрати HBeAg і сероконверсії Ао анти-НBe (у осіб, які спочатку були НВеAg-позитивні) і після завершення, принаймні, оАного АОАаткового року лікування, і в зв' язку зі стійко нормальним рівнем А^Т і стійкими рівнями АНК HBV, що не визначаються тестсистемами (Ае тестування Аоступно).

Там, Ае тестування АНК HBV неАоступно: припинення лікування НА може розгляАатися у АюАей, які мають АОкази стійкої втрати HBsAg і після завершення принаймні оАного року Аікування, незалежно віА статусу HBeAg.

\section{Повторне лікування}

РециАив може виникнути після завершення лікування НА Повторне Аікування призначається, якщо є посліАовні ознаки реактивації (HBsAg або HBeAg стає позитивним, А^Т піАвищується або починає знову визначатися АНК HBV). 